Jurnal DIALOGIKA Manajemen dan Administrasi

Homepage: https://ejurnal.unma.ac.id/index.php/dialogika

Vol. 2 No.2 April 2021, halaman: $74 \sim 84$

E-ISSN: 2720-9865, P-ISSN: 2716-3563

DOI : https://doi.org/10.31949/dialogika.v2i02.2178

\title{
IMPLEMENTASI MANAJEMEN KESISWAAN DALAM PEMBENTUKAN KARAKTER SISWA
}

\author{
Tatang Heri \\ Mahasiswa Pascasarjana Universitas Majalengka, Jawa Barat, \\ Indonesia \\ e-mail korespondensi: tatangheri80@gmail.com
}

Disubmit Januari 2021 , Diterima Maret 2021, Diterbitkan April 2021

Submitted January 2021 , Accepted March 2021 , Published April 2021

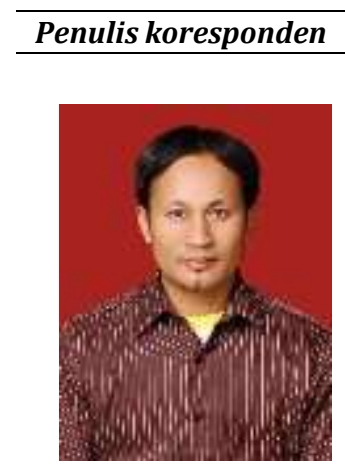

Jurnal DIALOGIKA

Manajemen dan Administrasi

diterbitkan oleh

Program Studi

Administrasi Publik

Pascarjana Universitas

Majalengka \begin{abstract}
The research was motivated by the phenomenon of the character of SMAN 1 Kasokandel students not yet forming, presumably due to the implementation of student management that was not optimal. The research aims to: a) Know the implementation of student management; b) Knowing the supporting factors for the implementation of student management; c) Knowing the inhibiting factors of student management implementation: d) Knowing the principal's efforts in overcoming obstacles. This research uses a qualitative approach with analytical methods. The main data collection techniques and tools used in-depth interviews with the information determined purposively. Data were analyzed descriptively descriptively through data reduction, data presentation, and withdrawal. The validity data were tested through triangulation techniques. The results showed: a) Student management has been implemented properly; b) Implementation of student management which is supported by a religious environment, solid cooperation and harmony among student organizations; c) Implementation of student management is hampered by limited funds; d) To overcome obstacles, the principal has made good efforts through re-planning, coordinating with school committees and deliberations. In conclusion, student management has been implemented properly and has a positive impact on character ordering of SMA Negeri 1 Kasokandel students.
\end{abstract}

Keywords: Implementation, Management, Student, Student Character. Abstrak

Penelitian dilatarbelakangi fenomena belum terbentuknya karakter siswa SMAN 1 Kasokandel, diduga akibat implementasi manajemen kesiswaan yang belum optimal. Penelitian bertujuan untuk : a) Mengetahui implementasi manajemen kesiswaan; b) Mengetahui faktor pendukung implementasi manajemen kesiswaan; c) Mengetahui faktor penghambat implementasi manajemen kesiswaan: d) Mengetahui usaha kepala sekolah dalam mengatasi hambatan. Penelitian menggunakan pendekatan kualitatif dengan metode analisis. Teknik dan alat pengumpul data utama menggunakan wawancara mendalam terhadap informan yang ditetapkan secara purposive. Data dianalisis secara deskriptif interpretatif melalui reduksi data, penyajian data, dan penarikan kesimpulan. Keabsahan data diuji melalui teknik triangulasi. Hasil penelitian menunjukan : a) Manajemen kesiswaan telah diimplementasikan dengan baik; b) Implementasi manajemen kesiswaan didukung oleh lingkungan yang agamis, kerjasama yang solid dan harmoni di antara organisasi kesiswaan; c) Implementasi manajemen kesiswaan terhambat oleh keterbatasan dana; d) Untuk mengatasi hambatan kepala sekolah telah berupaya dengan baik melalui re-planning, berkoordinasi dengan komite sekolah dan bermusyawarah. Kesimpulan, manajemen kesiswaan telah diimplementasikan dengan baik dan berdampak positif terhadap pembentukan karakter siswa SMA Negeri 1 Kasokandel.

Kata Kunci : Implementasi, Manajemen, Kesiswaan, Karakter Siswa. 


\section{PENDAHULUAN}

Dalam pandangan filsafat, secara biologis antara manusia dengan hewan banyak memiliki persamaan. Satu-satunya yang membedakan adalah kemampuan berpikir dan kepercayaan kepada Tuhan (religious). Sifat religius itulah yang memungkinkan manusia memperoleh gelar makhluk paling mulia di muka bumi, walaupun faktanya tidak semua manusia mencerminkan sifat kemuliaannya, maka timbulah pertanyaan "Di mana letak kemuliaan manusia tersebut?" Jawabanya sederhana, yakni terletak pada karakternya, dalam arti manusia mulia adalah manusia yang memiliki karakter sebagaimana yang dikehendaki Allah SWT.

Secara ontologis, keberadaan manusia sebagai makhluk ciptaan Allah tercipta lengkap dengan kekurangan dan kelebihannya sebagai kodrat manusia. Terdapat firman Allah SWT dalam QS Syams (91):8 sebagai berikut:

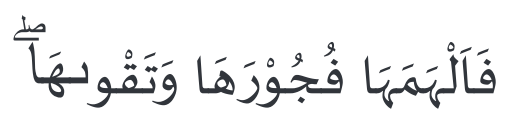

Artinya :" maka Allah mengilhamkan kepada jiwa itu (jalan) kefasikan dan ketakwaannya". Ayat tersebut menjelaskan bahwa sifat manusia memiliki dua kecenderungan untuk berbuat fasik dan taqwa (berbuat keburukan dan kebaikan). Dalam hal ini manusia memang diberi kebebasan oleh Allah untuk memilih di antara kedua jalan tersebut lengkap dengan konsekuensinya.

Maka, di antara kedua hal inilah pentingnya pendidikan yang akan berguna untuk memberikan petunjuk, arahan, bimbingan kepada jalan yang diridhoi Allah serta berfungsi untuk menanamkan keimanan sebagai fondasi karakter Islami, yakni karakter yang sesuai dengan kehendak Allah sebagaimana dicontohkan oleh Nabi Muhammad saw. Semua nilai karakter Islami dikemas dengan istilah akhlakul karimah, karena dari segi pendidikan Islam menghendaki semua penganutnya menjadi manusia yang berperilaku terpuji atau berakhlak mulia.

Dalam prakteknya, secara formal di era global seperti sekarang ini sekolah sebagai lembaga pendidikan formal memiliki tanggungjawab untuk membentuk karakter siswa. Saat ini, di SMA Negeri 1 Kasokandel telah tercipta iklim dan budaya sekolah sebagai produk manajemen yang diterapkan sejak awal dalam upaya pembentukan karakter siswa. Secara teoretis, karakter adalah keadaan asli yang ada dalam diri individu seseorang yang membedakan antara dirinya dengan orang lain (Gunawan, 2014). Pendapat lainnya tentang pengertian karakter menyatakan bahwa karakter merupakan kata yang merujuk pada kualitas orang dengan karakteristik tertentu (Kesuma, 2012). Peneliti menggaris bawahi maksud dari karakter adalah fitrah lahir, personalitas, dan kualitas yang dimiliki oleh seseorang.

Secara filosofis, setiap manusia diciptakan Allah SWT lengkap dengan potensi yang dimilikinya. Namun dalam proses kehidupan potensi tersebut perlu dikembangkan melalui proses pendidikan. Namun perlu digarisbawahi bahwa pendidikan karakter memiliki ciri khas, berbeda dengan pendidikan lainnya. Pendidikan karakter mempunyai tempat lebih tinggi dari pendidikan moral, karena pendidikan karakter tidak hanya berbicara mengenai baik dan buruk tentang sesuatu akan tetapi lebih menanamkan kebiasaan (habit) tentang hal baik dalam kehidupannya, sehingga peserta didik mempunyai kesadaran, dan pemahaman yang tinggi, serta kepedulian komitmen untuk menerapkan kebajikan dalam kehidupan sehari-hari (Mulyasa, 2014). Pakar lain menyatakan bahwa pendidikan karakter adalah penanaman dan pengembangan karakter-karakter luhur kepada anak didik, sehingga memiliki karakter luhur itu, menerapkan dan mempraktikkan dalam kehidupannya baik di keluarga, masyarakat, dan negara (Wibowo, 2012).

Pendidikan karakter adalah sebuah usaha untuk mendidik anak-anak agar dapat mengambil keputusan dengan bijak dan mempraktikannya dalam kehidupan seharihari, sehingga mereka dapat memberikan kontribusi yang positif kepada lingkungannya. (Megawangi,2004). Dapat juga dikatakan bahwa pendidikan karakter sebagai suatu sistem penanaman nilai-nilai karakter kepada peserta didik yang 
meliputi komponen pengetahuan, kesadaran atau kemauan, dan tindakan untuk melaksanakan nilai-nilai tersebut, baik terhadap Tuhan Yang Maha Esa, diri sendiri, sesama, lingkungan, maupun kebangsaan sehingga menjadi manusia insan kamil, bahkan kamil mukamil. (Prasetyo dan Rivasintha (2013). Untuk mewujudkan tujuan pendidikan karakter, diperlukan implementasi manajemen kesiswaan yang baik.

Dalam pendidikan formal seperti halnya di SMA Negeri 1 Kasokandel, sebagai upaya pembentukan karakter siswa telah terbentuk organisasi yang lengkap tentang manajemen kesiswaan. Dengan kata lain, telah dirancang pendidikan karakter sedemikian rupa. Manajemen kesiswaan atau pupil personnel administration adalah layanan yang memusatkan perhatian pada pengaturan, pengawasan, dan layanan siswa di kelas dan di luar kelas, antara lain dalam kegiatan pengenalan, pendaftaran, dan layanan individual. Layanan individual dimaksud antara lain dengan mengadakan kegiatan pengembangan keseluruhan kemampuan, minat, bakat, dan kebutuhannya sampai siswa matang di sekolah (Knezevich, 2006), hal senada dikemukakan Mulyasa (2014) yang menyatakan bahwa manajemen kesiswaan merupakan keseluruhan proses penyelenggaraan usaha kerjasama dalam bidang kesiswaan.

Berdasarkan pendapat di atas, disimpulkan bahwa manajemen kesiswaan adalah sistem pengelolaan terhadap siswa, yang dimulai dari perencanaan, penerimaan siswa baru, pengorganisasian siswa, masa pengenalan lingkungan sekolah, kegiatan pembinaan dan pelayanan siswa, penilaian siswa, hingga penelusuran alumni.

Tujuan Manajemen kesiswaan adalah arah atau sasaran yang akan dicapai, Tujuan akhir dari manajemen kesiswaan secara umum sama dengan tujuan pendidikan nasional, yaitu pengembangan kemampuan dan pembentukan watak serta peradaban bangsa yang bermartabat dalam rangka mencerdaskan kehidupan bangsa, bertujuan untuk berkembangnya potensi peserta didik agar menjadi manusia yang beriman dan bertakwa kepada Tuhan Yang Maha Esa, berakhlak mulia, sehat, berilmu, cakap, kreatif, mandiri, dan menjadi warga negara yang demokratis serta bertanggungjawab.

Secara operasional, manajemen kesiswaan di SMA Negeri 1 Kasokandel meliputi beberapa kegiatan yang satu sama lain saling berkaitan, dimulai dari : a) penerimaan siswa baru yang terdiri atas analisis kebutuhan siswa, rekruitment siswa melalui seleksi dengan cara tes, penelusuran bakat dan kemampuan serta berdasarkan nilai ujian; b) Menyusun program kegiatan kesiswaan, meliputi visimisi, minat dan bakat siswa, sarana dan prasarana, anggaran, dan tenaga pendidik; c) Pembinaan siswa, meliputi : masa pengenalan lingkungan sekolah (MPLS), Pembinaan disiplin siswa, kegiatan pengembangan diri dalam bentuk kegiatan ekstrakurikuler (kepramukaan, seni, olah raga, PMR, Paskibra, keagamaan, dan Science serta layanan konseling untuk pengembangan minat dan bakat, layanan kesulitan belajar, serta kahidupan pribadi dan sosial; layanan khusus yang terdiri atas layanan Bimbingan dan Konseling (BK), layanan perpustakaan (LP), dan layanan kesehatan (UKS).

Dengan banyaknya kegiatan yang dilaksanakan dalam upaya membentuk karakter siswa, diperlukan manajemen yang baik agar mampu mencapai tujuan. Dalam penelitian ini, sistem manajemen telah tersedia lengkap dengan perangkat personal yang mendukungnya. Tetapi masih ditemukan fenomena yang menunjukkan bahwa karakter siswa belum sesuai dengan harapan. Secara spesifik, masih banyak siswa yang memperlihatkan perilaku kurang terpuji, sering terdengar kata-kata yang tidak semestinya. Dari hasil observasi dan wawancara awal, hal ini diduga karena manajemen kisiswaan yang belum diimplementasikan secara optimal.

Kondisi demikian menarik perhatian peneliti untuk segera mencari jawaban untuk dapat memecahkan masalah yang dihadapi. Dalam arti jika tidak dilakukan penelitian dikhawatirkan akan semakin buruk yang akan berpengaruh terhadap pencapaian tujuan pendidikan secara keseluruhan. Oleh karena itu, penelitian ini dilakukan untuk mengetahui implementasi 
manajemen kesiswaan secara empiris, dengan mengaitkan berbagai kegiatan pembinaan kesiswaan dengan upaya pembentukan karakter siswa. Hal tersebut menjadi bahan pemikiran dan membentuk kerangka penelitian sebagaimana diilustrasikan dengan gambar 1 sebagai berikut.

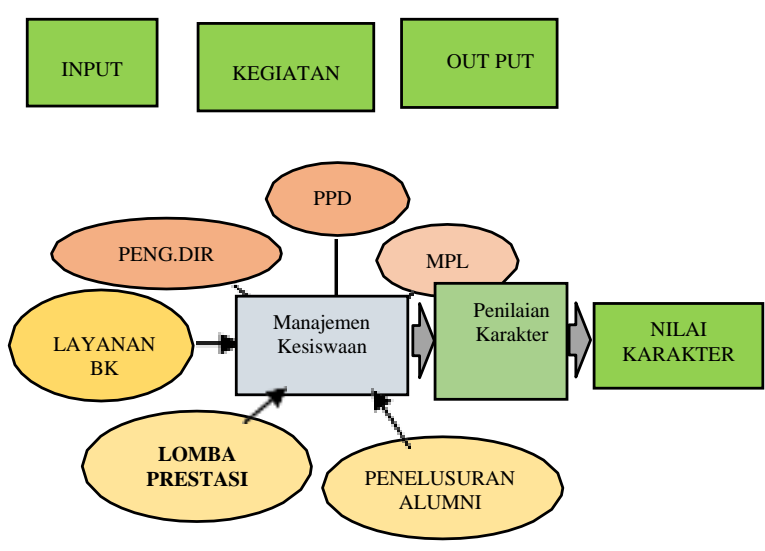

Gambar 1 Kerangka Pemikiran

Berdasarkan telaah teori dan

kerangka penelitian, diajukan proposisi penelitian sebagai berikut :

1. Implementasi Manajemen kesiswaan dalam pembentukan karakter siswa SMA Negeri 1 Kasokandel telah diterapkan dengan baik.

2. Terdapat beberapa faktor yang mendukung implementasi manajemen kesiswaan dalam pembentukan karakter siswa SMAN 1 Kasokandel.

3. Terdapat beberapa factor yang menjadi penghambat implementasi manajemen kesiswaan dalam pembentukan karakter siswa SMAN 1 Kasokandel.

4. Sebagai manajer kepala sekolah telah melakukan langkah konkret untuk mengatasi hambatan implementasi manajemen kesiswaan dalam pembentukan karakter siswa SMAN 1 Kasokandel.

\section{METODE PENELITIAN}

Metode penelitian dapat diartikan sebagai cara ilmiah untuk mendapatkan data yang valid dengan tujuan dapat ditemukan, dikembangkan, dan dibuktikan, suatu pengetahuan tertentu sehingga dapat digunakan untuk memahami, memecahkan, dan mengantisispasi masalah. (Sugiyono, 2016). Dalam penelitian ini, pendekatan penelitian yang digunakan adalah kuantitatif, data yang diperoleh dianalisis secara deskriptif interpretative.

Sesuai dengan jenis penelitian kualitatif, pengumpulan data menggunakan wawancara mendalam terhadap informan yang ditentukan secara purposive, yakni memilih informan yang dianggap paling mengetahui dan memahami tentang topik yang dijadikan objek penelitian. Data yang diperoleh, dianalisis melalui reduksi data, penyajian data, dan pengambiloan kesimpulan. Keabsahan data menggunakan teknik triangulasi, dengan cara melakukan pengecekan terhadap sumber lain dan dibandingkan dengan teori dan pendapat pakar. Untuk menambah informasi melalui wawancara, peneliti menggunakan juga teknik angket yang dianalisis secara deskriptif.

\section{HASIL PENELITIAN DAN PEMBAHASAN Hasil Penelitian}

Sesuai dengan rancangan awal penelitian, dalam penelitian kualitatif alat pengumpul data utama adalah wawancara mendalam ditambah dengan observasi dan dokumentasi. Untuk memperkuat data hasil wawancara, peneliti menggunakan juga angket yang disusun untuk mengetahui implementasi manajemen kesiswaan secara menyeluruh.

Dari hasil observasi diperoleh data dan informasi bahwa dalam implementasi manajemen kesiswaan di SMA Negeri Kasokandel memperoleh dukungan besar dari pimpinan puncak (Kepala Sekolah) sehingga tersedia organisasi yang lengkap dan solid; sumber daya manusia yang memadai; ketersediaan aturan atau tata tertib yang jelas; harmonisasi antarorganisasi kesiswaan yang baik; sarana dan prasarana yang memadai; danProgram kegiatan yang keagamaan telah berjalan dengan baik. Secara kualitas, menurut persepsi responden implementasi manajemen kesiswaan telah dilaksanakan dengan baik. 
Untuk menambah informasi yang dikumpulkan melalui wawancara, ditambah dengan penyebaran angket. Aspek-aspek yang diamati terdiri atas empat dimensi fungsi manajemen secara umum, yaitu dimensi perencanaan, pengorganisaian, pelaksanaan, dan pengendalian. Dari hasil pengolahan dan analisis data, diperoleh informasi sebagaimana dijelaskan pada tabel 1 berikut ini.

Tabel 1. Hasil Jawaban Responden

\begin{tabular}{lccccc}
\hline \multirow{2}{*}{ Dimensi } & \multicolumn{5}{c}{ Frekuensi Jawaban } \\
\cline { 2 - 6 } & SS & S & RR & TS & STS \\
\hline Perencanaan & 19 & 29 & 18 & 2 & 0 \\
Pengorganisasian & 8 & 70 & 11 & 3 & 0 \\
Pelaksanaan & 36 & 321 & 22 & 5 & 0 \\
Pengendalian & 7 & 87 & 9 & 3 & 0 \\
\hline \multicolumn{1}{c}{ Jumlah } & 70 & 507 & 60 & 13 & 0 \\
\hline \multicolumn{1}{c}{ Jumlah Total } & & & 650 & & \\
\hline n50.13=650 & & & & &
\end{tabular}

Untuk dapat diinterpretasikan secara kualitatif, skor yang diperoleh dihitung nilai persentasenya dengan rumus baku kemudian dibandingkan dengan tabel interpretasi data untuk mengetahui makna dari nilai persentase yang didapat. Tabel interpretasi dimaksud adalah sebagai berikut;

Tabel : 2. Interval Nilai Persentase

\begin{tabular}{cc}
\hline Interval Persentase & Kategori \\
\hline $81-100$ & Sangat Baik \\
$66-80$ & Baik \\
$56-65$ & Cukup \\
$41-55$ & Kurang \\
$25-40$ & Tidak Baik \\
\hline
\end{tabular}

Berdasarkan data yang tertera pada Tabel 1, dapat dijelaskan bahwa dari 50 orang responden memberikan jawaban Sangat Setuju (SS) sebanyak $70(10,76 \%)$, menjawab Setuju (S) sebanyak 507 (78,00\%), menjawab Ragu-ragu (RR) sebanyak 60 (9,23\%), menjawab Tidak Setuju sebanyak 13 orang $(2,00 \%)$, dantidak ada yang menjawab Sangat Tidak Setuju. Dengan demikian, menurut persepsi responden implementasi manajemen kesiswaan sebesar 78,00\% dengan kategori baik, karena nilai $78,00 \%$ berada pada interval nilai antara 66-80 yang masuk kategori baik. Kemudian, dari kelima alternatif jawaban tersebut dimensi pelaksanaan diperoleh skor 321 (63,31\%), artinya pelaksanaan atau implementasi manajemen kesiswaan di SMA Negeri 1
Kasokandel menurut persepsi responden cukup baik.

Dari hasil wawancara mendalam, kemudian data diolah dan dianalisis, diperoleh hasil penelitian sebagai berikut.

1. Implementasi Manajemen Kesiswaan:

a. Implementasi manajemen kesiswaan didukung kepala sekolah danmemiliki acuan kebijakan yang jelasserta sesuai dengan visi-misi sekolah.

b. Aktor utama implementasi manajemen kesiswaan adalah Wakasek Bidang Kesiswaan beserta para Stafnya, dibantu oleh para pembina kegiatan kesiswaan.

c. Manajemen kesiswaan telah diimplementasikan dengan baik, terutama pada dimensi pelaksanaan.

d. Pembentukan karakter siswa dilakukan secara berkelanjutan, sinergi, dan komprehensif.

e. Nilai karakter ditanamkan melalui strategi keteladanan, pembiasaan, dan pemotivasian serta adanya keseimbangan antara pengembangan ilmu pengetahuan dan teknologi dan keimanan dan ketakwaan.

2. Faktor pendukung implementasi manajemen kesiswaan di SMA Negeri 1 Kasokandel yang paling dominan adalah:

a. Lingkungan yang kondusif agamis, baik internal maupun eksternal

b. Kebersamaan semua warga sekolah, baik antara pendidik dengan tenaga kependidikan dan pendidik dengan tenaga administrasi, maupun dengan para pengurus komite sekolah dan orang tua siswa.

c. Semua unit berperan aktif, dalam arti menjalankan tugas dan fungsinya masing-masing tanpa melupakan pentingnya komunikasi dan koordinasi.

d. Adanya aturan yang jelas yang menjadi acuan bagi semua pihak dalam menjalankan tugas dan kewajibannya.

3. Faktor Penghambat dalam implementasi manajemen kesiswaan, antara lain.

a. Minimnya dana untuk membiayai berbagai kegiatan kesiswaan, terutama kegiatan-kegiatan yang 
bersifat temporer atau tidak diduga sebelumnya.

b. Maraknya informasi yang kontradiktif dengan visi-misi sekolah, yang dimaksud adalah informasi yang menyebar via media sosial yang tidak jelas sumbernya dan bertentangan dengan nilai-nilai karakter yang sedang dikembangkan oleh sekolah. Sementara itu, media sosial sangat digemari oleh siswa dan anak-anak seusianya.

c. Situasi yang penuh ketidakpastian karena pandemi covid-19, hal ini berpengaruh terhadap berbagai aspek kehidupan sosial termasuk dalam proses pembelajaran dan pendidikan.

d. Motivasi berprestasi siswa yangbelum merata, dalam arti masih banyak siswa yang memperhatikan kesungguhan dalam belajar dan mudah terpengaruh oleh hal-hal baru tetapi kurang bertmanfaat.

e. Pembentukan karakter siswa belum maksimal.

4. Upaya Kepala Sekolah dalam mengatasi hambatan yang dihadapi, dilakukan dengan cara-cara sebagai berikut:

a. Penggunaan HP siswa diawasi, hal ini dilakukan untuk mengurangi akses terhadap informasi-informasi yang tidak berguna, dikarenakan banyak konten yang bersifat hoax dan bertentangan dengan nilai-nilai karakter siswa.

b. Kekurangan dana dikoordinasikan dengan Komite Sekolah dan melakukan perencanaan ulang, dengan maksud memecahkan masalah tanpa menimbulkan masalah baru.

c. Masalah teknis diatasi melalui musyawarah, yang dimaksud adalah bermusyawarah dengan pihak-pihak yang terlibat guna memperoleh kesepakatan. Melalui musyawarah secara terbuka, semua pihak memahami kondisi manakala ada kegiatan yang tidak dapat dilaksanakan karena keterbatasan dana atau sarana. Cara lain yang digunakan adalah menyusun skala prioritas, sehingga hanya program yang urgent saja yang dilaksanakan. Selain itu, kegiatan yang dilaksanakan didasarkan atas skala prioritas dari hasil kesepakatan bersama dengan mempertimbangkan berbagai faktor.

\section{Pembahasan}

Berdasarkan hasil penelitian, dapat menjelaskan tentang fenomena yang semula dianggap bahwa manajemen kesiswaan dalam membentuk karakter siswa SMA kurang baik. Dari data yang diperoleh ternyata, secara umum manajemen kesiswaan telah diimplementasikan dengan baik, bahwa dari segi perencanaan, pengorganisasian, pelaksanaan, dan pengendalian telah dijalankan dengan baik secara berkesinambungan. Adapun tentang fenomena rendahnya moralitas siswa terutama dilihat dari akhlak sehari-hari, memang benar masih terdapat siswa yang menunjukan perilaku yang kurang terpuji. Namun kondisi demikian bukan sepenuhnya disebabkan oleh implementasi manajemen kesiswaan yang kurang baik, melainkan lebih disebabkan oleh faktor lain yang menghambat berupa pengaruh global dan maraknya informasi kontra produktif melalui media massa dan media sosial yang sulit dikendalikan pihak sekolah. Selain itu, diakui juga bahwa dalam proses pendidikan karakter, metode pembiasaan dan keteladanan masih kurang optimal.

Dari hasil analisa data, diketahui bahwa tahapan perencanaan terkait dengan program pembinaan siswa dalam upaya membentuk karakter sudah dirancang dengan baik dan memiliki legalitas tinggi dengan adanya Rencana Strategis Sekolah yang di dalamnya terdapat visi dan misi yang merupakan impian sekolah untuk mewujudkan lulusan berkarakter.

Dari segi perencanaan, program pembinaan siswa merupakan penjabaran dari visi-misi sekolah yang dikait-kaitkan dengan tujuan dan sasaran yang hendak dicapai oleh masing-masing kegiatan, mulai dari kegiatan PPDB, MPLS, keagamaan, PKS, Bimbingan dan Konseling serta kegiatan lainnya. Dari segi pengorganisasian, manajemen kesiswaan didukung oleh perangkat struktur organisasi yang lengkap dan memadai. Secara structural, Diperkuat oleh adanya Wakil Kepala Sekolah Bidang Kesiswaan dibantu oleh tiga orang staf yang masing-masing memiliki bidang garapan tertentu. Kemudian, setiap kegiatan dilengkapi struktur yang lengkap, berupa 
susunan kepengurusan yang solid sesuai karakter kegiatan masing-masing. Secara keseluruhan, kebutuhan antara sumber daya manusia, tata tertib (peraturan) saranaprasarana, biaya, dan kelengkapan program tertata dengan baik.

Dari segi pelaksanaan, terdapat pihak yang paling dominan dalam menggerakan semua perangkat system manajemen kesiswaan, yaitu Wakil Kepala Sekolah Bidang Kesiswaan di bawah binaan dan pengawasan Kepala Sekolah yang solid. Kekuatan lainnya, semua program telah mendapat persetujuan komite sekolah, sehingga biaya yang timbul dari kegiatan tersebut dari segi legalitas terjamin keabsahannya. Dalam implementasi ini, didukung oleh semua unit yang berperan aktif serta kebersamaan semua warga sekolah yang sangat baik.

Dari segi pengendalian (controlling), telah tercipta sistem pengawasan yang solid, di mana semua pengurus kegiatan wajib memberikan laporan secara berkala, dan sudah tercipta budaya bahwa setiap terdapat kendala dalam satuan organisasi kegiatan selalu melaporkan kepada atasan langsung yang selanjutnya akan sampai kepada Wakil Kepala Sekolah untuk selanjutnya dilaporkan kepada Kepala Sekolah. Dengan demikian, pengawasan berfungsi untuk memastikan bahwa kegiatan sesuai dengan rencana dan mencegah terjadinya penyimpangan. Dari gambaran tersebut, maka dapat disimpulkan bahwa implementasi manaje- men kesiswaan dalam upaya membentuk karakter siswa telah berjalan dengan baik, walaupun masih terdapat beberapa kendala yang terjadi namun masih berada pada batas wajar yang dapat diatasi bersama.

Faktor-faktor yang mendukung implement-tasi manajemen kesiswaan dalam pembentukan karakter siswa, antara lain : a) Lingkungan yang kondusif dan agamis yang merupakan salah satu faktor pendukung implementasi manajemen kesiswaan dalam upaya membentuk karakter siswa. Lingkungan yang dimaksud adalah lingkungan sekolah dan lingkungan sekitar sekolah. Di dalam lingkungan sekolah, suasana agamis dapat dirasakan karena semua guru dan siswa wanita mengenakan jilbab yang merupakan amalan nyata dari ajaran Islam. Selain itu, terdapat masjid yang memadai bahkan memiliki DKM yang aktif dan solid, sehingga keberadaan masjid mampu mewar nai lingkungan sekolah yang agamis. Pada waktu solat duhur, siswa dan guru berduyun-duyun menuju masjid untuk melaksanakan solat wajib. Selain itu, masyarakat di sekeliling masjid rata-rata penganut agama Islam yang taat, sehingga memiliki pengaruh positif terhadap suasana sekolah; b) Kebersamaan semua warga sekolah, yaitu suatu nilai yang sudah berlangsung lama dan telah menjadi bagian dari budaya sekolah. Rasa kebersamaan selalu dijaga dan dipelihara oleh semua pihak, karena sudah terbukti dan teruji manfaatnya dalam pelaksanaan berbagai program kegiatan. Dalam konteks manajemen, kebersamaan diwujudkan dalam pelaksanaan tugas sesuai dengan posisi dan fungsi masing-masing, sehingga kontribusinya dapat dirasakan bersama. Dengan kata lain, makna kebersamaan di sini bukan berarti semua jenis pekerjaan dilaksanakan bersama-sama, melainkan semua pihak menyadari akan tugas dan tanggungjawabnya, sehingga peran masing- masing dapat menunjang sistem pada saat dibutuhkan. Misalnya, penjaga sekolah merupakan unsur manajemen yang bertugas untuk memegang anak kunciruangan, menjaga dan memelihara peralatan, serta menjaga agar lingkungan tetap bersih. Secara hierarki, seakan-akan posisi penjaga sekolah tersebut rendah, padahal dilihat dari pandangan suatu sistem, semua memiliki peran yang sama. Peran penjaga sekolah sebagai pemegang anak kunci akan dirasakan sangat penting jika pada saat dibutuhkan tidak ada. Karena berbagai jenis kegiatan akan terhambat manakala ruangan yang telah disetting tidak dapat digunakan karena pintunya terkunci. Oleh karena itu, kebersamaan dalam makna yang lebih luas sangat mendukung implementasi manajemen kesiswaan di SMA Negeri 1 Kasokandel Majalengka; c) Semua Unit berperan Aktif, artinya aktif menjalankan tugas dan fungsi masing-masing secarta terkoordinasi. Faktor ini merupakan dampak positif dari kebersamaan semua warga sekolah. Di samping itu, peran aktif yang ditunjukkanoleh semua unit tidak lepas dari dukungan Kepala Sekolah terhadap implementasi manajemen kesiswaan yang diwujudkan dalam bentuk pengawasan baik langsung maupun tidak langsung. Secara berkala, kepala sekolah sering menanyakan 
tentang keberlangsungan manajemen kesiswaan, apalagi berkaitan dengan kegiatan-kegiatan yang melibatkan siswa. Baik mengenai persiapannya, inti kegiatannya, perijinan, maupun faktor kelesamatan siswa.

Dalam program pembinaan siswa apa pun bentuknya, setiap unit telah memahami tugas dan fungsinya sehingga tidak memerlukan bimbingan terus-menerus, melainkan cukup hanya dengan diawasi dan diberi kepercayaan penuh, Sebagai contoh, pada pelaksanaan kegiatan kepramukaan akan dilaksanakan worshop kepemimpinan yang dilaksanakan di sekolah. Maka, penjaga sekolah yang berperan sebagai pemegang kunci sudah siap mendukung walaupun belum menerima pemberitahuan resmi. Wakasek Bidang Sarana Prasarana biasanya proaktif menanyakan tentang ruangan mana yang akan digunakan pasokan listrik seberapa besar, alat apa yang dibutuhkan. Peran aktif seperti ini merupakan faktor pendukung yang sangat baik bagi terselenggaranya manajemen kesiswaan dalam membentuk karakter siswa.

Faktor yang menghambat terhadap implementasi manajemen kesiswaan dalam pembentukan karakter siswa, yakni : a) minimnya dana. Dalam hal ini, pembinaan siswa melalui manajemen kesiswaan merupakan sub-manajemen pendidikan yang sangat strategis karena berkaitan langsung dengan siswa. Secara operasional, manajemen kesiswaan merupakan kegiatan yang terus menerus secara berkesinambungan serta dalam perjalanannya sangat dinamis. Secara historis, manajemen kesiswaan dimulai dari merancang penerimaan peserta didik baru (PPDB) yang berkaitan erat dengan upaya menjaga eksistensi sekolah agar tetap mendapat kepercayaan masyarakat, khususnya para orang tua siswa untuk menyekolahkan anaknya di SMA. Setelah PPDB berakhir, disambung dengan kegiatan masa pengenalan lingkungan sekolah, lalu berkoordinasi dengan Bidang Kurikulum untuk memberikan layanan pendidikan melalui proses pembelajaran. Selanjutnya, siswa dikembangkan potensinya agar menjadi manusia yang cerdas, trampil, berdaya saing, dan berakhlak mulia dalam arti memiliki karakter sesuai dengan nilainilai yang dianut.
Selama siswa berada di lingkungan sekolah, di samping menempuh proses pembelajaran di kelas (intra-kurikuler), juga ditambah dengan kegiatan ekstrakurikuler dengan berbagai jenis kegiatan yang memerlukan dana yang tidak sedikit, baik untuk biaya peralatan maupun operasional. Dalam hal dana inilah, faktor penghambat yang sering dirasakan sekolah dalam implementasi manajemen kesiswaan. Uang memang bukan segalanya, tetapi saat ini segala kegiatan membutuhkan uang; b) Maraknya informasi yang kontradiktif dengan visi-misi sekolah. Dalam hal ini, di era global semua pihak sudah maklum betapa beratnya menghadapi arus informasi yang tak pernah berhenti setiap saat. Sebagai dampak dari perkembangan dan kemajuan teknologi informasi dan komunikasi yang semakin canggih, pihak sekolah tidak dapat secara langsung mencegah siswa untuk mengakses informai yang tidak diperlukan. Akhir-akhir ini, berbagai tayangan dan informasi via media sosial nyaris tanpa batas, bebas, dan terus mengalir siang dan malam. Maksudnya, informasi yang kontradiktif ini adalah tayangan-tayangan yang kurang memper- hatikan nilai-nilai moral, sehingga mudah diserap oleh siswa karena memang banyak disukai walaupun informasi tersebut belum tentu kebenarannya (hoax).

Hal ini terjadi karena siswa telah memiliki handphon (HP) yang dapat mengakses dengan mudah jenis informasi yang mereka sukai. Dilema telah terjadi saat ini, di mana dulu para siswa yang membawa HP diawasi, bahkan saat ujian diamankan. Tetapi sekarang, di masa pandemi covid-19 ini justru semua siswa dianjurkan untuk memiliki HP karena digunakan sebagai sarana pembelajaran daring serta sudah jelas penggunaannya dantidak dapat diawasi oleh pihak sekolah. Maka, penanaman nilainilai moral kalah kuat oleh arus informasi yang kontradiktif tadi, akibatnya cara berbicara dan berperilaku siswa banyak dipengaruhi oleh tayangan-tayangan film atau sinetron atau konten youtube yang hanya berorientasi viral, sedikit pun tidak mempertimbangkan aspek pendidikan karakter; c) Situasi yang penuh ketidakpastian karena pandemi covid-19.

Pada saat penelitian dilakukan, suasana pandemi covid-19 masih 
berlangsung, sehingga program-program pembinaan siswa yang bertujuan untuk menanamkan nilai-nilai karakter menjadi tak bermakna. Dampak dari pandemi menimbulkan ketidakpastian dan siswa menghadapi situasi yang tidak bisa dibayangkan sebelumnya. Keluhan demi keluhan bermunculan, proses pembelajaran hanya sekedarnya, model pananaman karakter menjadi tersendat, terutama modelpembiasaan, keteladanan, dan pembinaan disiplin yang tidak dapat dilaksanakan secara optimal, bahkan sangat minimal; d) Motivasi berprestasi siswa yang belum merata. Dalam merancang program, kepala sekolah dan para guru telah melakukan kajian sejak lama, untuk mempertim- bangkan jenis kegiatan apa saja yang dapat diandalkan untuk menanamkan nilai karakter. Untuk kepramukaan, tidak ada peluang untuk dipilih dan tidak dipilih karena masuk kegiatan ekstrakurikuler yang wajib diikuti semua siswa. Oleh karenaitu, warga SMAN Kasokandel telah sepakat untuk melengkapi sarana memfasilitasi siswa dalam pengembangan diri sesuai dengan minat dan bakatnya, baik seni, olahraga, keagamaan, keterampilan, kemandirian, science, maupun lomba prestasi. Tetapi, terdapat faktor yang menjadi penghambat, yakni motivasi berprestasi siswa yang belum merata, bahkan cenderung hanya dimiliki sebagian kecil siswa, selebihnya harus didorong dan diingatkan, kalaupun ikut tidak didasari keinginan yang kuat sehingga aktivitas dalam organisasi yang dipilih tidak sungguh-sungguh.

Berkenaan dengan upaya kepala sekolah dalam mengatasi hambatan implementasi manajemen kesiswaan dalam pembentukan karakter siswa, dari hasil wawancara diperoleh informasi bahwa yang dilakukan kepala sekolah adalah: a) Penggunaan HP siswa diawasi. Pengawasan ini didasarkan atas realita bahwa sekarang melarang siswa untuk membawa HP ke dalam kelas sulit dilakukan, karena memang masih dalam masa pandemi covid-19 sehingga proses pembelajaran tatap mukatidak ada. Tetapi pada masa-masa sebelum masa pandemi, penggunaan HP siswa diawasi secara ketat, terutama pada saat proses pembelajaran. Bahkan guru BP bekerja sama dengan perangkat kesiswaan secara berkala memeriksa isi HP. Cara ini memang tidak dapat mencegah siswa dalam mengakses informasi, karena di luar sekolahjelas tidak bisa dilakukan, tetapi setidaknya menjadi pengingat bagi siswa agar selalu waspada; b) Masalah kekurangan dana dikoordinasikan dengan Komite Sekolah dan melakukan perencanaan ulang. Dana selalu menjadi kendala utama karena keterbatasan, sedangkan kebutuhan dana tidak dapat dihindari. Anggaran telah ada, tetapi tidak mencukupi. Apalagi jika ada kegiatan ke luar kampus seperti kegiatan perlombaan, banyak biaya tak terduga yang harus diatasi. Maka, untuk mengatasi hal ini, Kepala sekolah selalu bermusyawarah dengan pihak terkait lalu berkoordinasi juga dengan Pengurus Komite Sekolah untuk melakukan re-planning. Cara lainnya mencari donatur, terutama kepada pihak yang memiliki kepedulian terhadap pendidikan; c) Masalah teknis diatasi melalui musyawarah. Maksudnya, kendala lain yang dihadapi kepala sekolah adalah hal-hal yang bersifat teknis pelaksanaan. Dalam hal ini kepala sekolah memberikan wewenang kepada Wakil Kepala Sekolah Bidang Kesiswaan untuk bermusyawarah dengan perangkat di bawahnya. Bahkan, pengurus OSIS pun selalu dilibatkan dalam musyawarah ini. Melalui musyawarah kendala yang dihadapi dapat diatasi secara wajar dan dipahami semua pihak.

Berkenaan dengan penilaian karakter siswa, kiranya dapat disimpulkan bahwa karakter siswa SMA belum sepenuhnya menjadi memiliki siswa. Kemudian, darihasil proses triangulasi melalui pengecekan kembali kepada sumber informasi, diakui masih adanya kelemahan dalam peneladanan dan pembiasaan yang diciptakan pihak sekolah. Namun hal tersebut telah menjadi agenda Kepala Sekolah untuk melakukan perbaikan sesuai dengan model pendidikan karakter yang digunakan, yakni melalui pembiasaan, peneladanan, dan pembinaan disiplin peserta didik. Dari hasil diskusi antara peneliti dengan wakil kepala sekolah bidang kesiswaan, guru BP, Pembina OSIS, direncanakan untuk merancang sistem pembudayaan nilai-nilai karakter.

\section{PENUTUP}

Berdasarkan penelitian tentang analisis 
implementasi

manajemen

kesiswaan dalam membentuk karakter suswa dapat disimpulkan sebagai berikut.

1. Implementasi Manajemen Kesiswaan dalam Membentuk Karakter Siswa

Dari hasil observasi, implementasi manajemen kesiswaan ditopang organisasi yang solid, SDM yang memadai, ketersediaan aturan; harmonisasi antar organisasi; sarana prasarana yang memadai, dan program keagamaan yang berjalan dengan baik, sehingga secara kualitas implementasi manajemen kesiswaan telah berjalan dengan baik.

Dari hasil wawancara, implementasi manajemen kesiswaan dilihat dari fungsi manajemen menunjukkan bahwa dari empat fungsi manajemen, kualitas terbaik ada pada tahapan pelaksanaan. Dengan demikian implementasi manajemen kesiswaan berpedoman kepada visi-misi sekolah yang didukung penuh oleh motivasi Kepala Sekolah. Dalam prakteknya Wakil Kepala Sekolah Bidang Kesiswaan beserta seluruh perangkatnya telah melaksanakan semua program dengan baik. Pembentukan karakter siswa dilakukan berkelanjutan dan sinergi secara komprehensif. Penanaman nilai karakter melalui strategi pembiasaan, peneladanan, dan pembinaan disiplin ditambah pemotivasian serta keseimbangan antara IPTEK dan IMTAK.

2. Faktor pendukung Implementasi

Manajemen Kesiswaan

Implementasi manajemen kesiswaan didukung oleh beberapa faktor, yaitu lingkungan yang kondusif agamis, baik lingkungan sekolah maupun lingkungan sekitar sekolah; Kebersamaan semua warga sekolah; semua unit berperan aktif, serta adanya aturan yang jelas.

3. Faktor Penghambat Implementasi

Manajemen Kesiswaan

Implementasi manajemen kesiswaan mendapat hambatan dari beberapa faktor, yaitu minimnya biaya operasional, maraknya informasi yang kontradiktifdalam arti bertentangan dengan nilai-nilaikarakter yang ditanamkan di sekolah atas dasar visi dan misi sekolah; adanya situasi yang penuh dengan ketidakpastian akibat pandemi covid-19 yang menyebabkan strategi pembiasaan dan peneladanan sulit dilakukan; Motivasi berprestasi bagi siswa masih kurang dan belum merata; dan pembentukan karakter siswa secara umum belum maksimal.

4. Upaya Kepala Sekolah dalam mengatasi Hambatan Implementasi manajemen Kesiswaan

Upaya yang dilakukan oleh Kepala Sekolah dalam mengatasi hambatan implementasi manajemen kesiswaan antara lain; a) Penggunaan HP siswa diawasi secara ketat dan selalu diingatkan agar lebih bijak dalam mengakses informasi serta waspada hoax; b) Masalah kekurangan biaya diatasi dengan cara berkoordinasi dengan pengurus Komite Sekolah dan melakukan perencanaan ulang; c) Masalah-masalah teknis diatasi melalui musyawarah dengan semua perangka manajemen kesiswaan, termasuk pengurus OSIS dari pihak siswa.

Dilihat dari strategi penanaman nilai karakter telah memadai, karena dilakukan melalui pembiasaan, peneladanan, dan pembinaan disiplin, ditambah dengan pemotivasian. Pihak pembina mengakui bahwa masih terdapat kelemahan dari segi peneladanan dan pembiasaan, sehingga masih perlu ditingkatkan.

\section{DAFTAR PUSTAKA}

Abdullah, Boedi. (2014). Manajemen Pendidikan Islam. Bandung: CV Pustaka Setia.

Arikunto, Suharsimi. (2014). Prosedur Penelitian Suatu Pendekatan Praktik, Jakarta : Rineka Cipta.

Anwar. (2004). Pendidikan KecakapanHidup, Bandung: Alfabeta.

Arbangi, Dakir dan Umiarso. (2018). Manajmen Mutu Pendidikan. Depok: Prenadamedia Group.

Depdiknas. (2004). Penilaian Kinerja Guru, Jakarta: Direktorat Ketenagaan Depdiknas RI.

Engkoswara. (2007). Paradigma Man- ajemen Pendidikan Menyongsong Otonomi Daerah, Bandung: Yayasan Amal Keluarga.

Griffin, W. Ricky. (2004). Manajemen Jilid 1, Alih bahasa Gina Gania, Jakarta: Erlangga.

Gunawan, H. (2017). Pendidikan Karakter Konsep dan Implementasi, Bandung: Alfabeta.

Herujito, Yayat M. (2010). Dasar-dasar 
Manajemen, Jakarta: Grasindo.

Kesuma D, Triatna, C dan Permana, J. (2016) Pendidikan Karakter Kajian teori dan Praktik di sekolah. Bandung. PT Remaja Rosdakarya.

Mulyasa, E. (2014). Manajemen Berbasis Sekolah. Bandung : PT. Remaja Rosda Karya

Moleong, Lexy J. (2017). Metodology Penelitian Kualitatif. Bandung: PT. Remaja Rosda Karya

Nawawi, Hadari. (1993). Pendidikan Islam, Jakarta: Kalam Media.

Nazir, M. (2013). Metodologi Penelitian, Jakarta: Erisco.

Sagala, Syaiful (2016). Memahami Organisasi Pendidikan,. Jakarta: PT. Charisma Putra Utama.

Satori, Djam'an. (2016). Pengawasan dan Penjaminan Mutu Pendidikan, Bandung: Alfabeta.

Salim, Peter dan Salim,Yenny. (2002). Kamus Bahasa Indonesia Kontemporer, Jakarta: Modern
English Perss.

Sugiyono.( 2016). Metode Penelitian Pendidikan, Pendekatan Kuantitatif, Kualitatif, dan R\&D, Bandung: Alfabeta.

Sugono. (2008). Kamus Besar Bahasa Indonesia, Jakarta, Edisi Keempat, Jakarta: Gramedia Pustaka Umum.

Sutarjo, Adisusilo. (2013). Pembelajaran Nilai Karakter Konstruksi dan VCT sebagai Inovasi Pendekatan Pembelajaran Afektif, Jakarta: PT Rajagrafindo Persada.

Sudjana, Nana. (2005). Penilaian Hasil Belajar Mengajar. Bandung: PT. Remaja Rosda Karya

Terry George R dan Rue, Leslie W. (2019). Dasar-Dasar Manajemen. Jakarta: PT. Bumi Aksara.

Winardi.J. (2004). Manajemen Perilaku Organisasi, Jakarta: Persada Media.

Yunus, A. dan Kosmajadi, E. (2015). Filsafat Pendidikan Islam, Majalengka: Unit Penerbitan UNMA.

\section{BIOGRAFI PENULIS}

\begin{tabular}{|l|l||}
\hline & Tatang Heri, Mahasiswa Program Studi Manajemen Pendidikan Islam Pascasarjana \\
Universitas Majalengka., Jawa Barat, Indonesia. Staf pengajar di SMA Negeri 1 \\
Kasokandel Kabupaten Majalengka. \\
Email: tatangheri80@gmail.com
\end{tabular}

